\title{
Research with children: reading of Emmanuel Lévinas and the otherness
}

Francine Ramos de Miranda ${ }^{1}$, Israel Fabiano Pereira de Souza ${ }^{2}$, Paulo Roberto Haidamus de Oliveira Bastos ${ }^{3}$, Maria Angélica Marcheti ${ }^{4}$, Maria Lúcia Ivo ${ }^{5}$, Alexandra Maria Almeida Carvalho ${ }^{6}$, Isabelle Campos de Azevedo ${ }^{7}$, Marcos Antonio Ferreira Júnior ${ }^{8}$

\begin{abstract}
Concern over delimiting research involving children, and more importantly the necessity of considering such research from an ethical perspective, is a recent development. With the aim of broadening this discussion, a form of ethical approach believed to be essential for the development of research with children was sought, based on the thinking of the philosopher Emmanuel Lévinas. Based on the otherness of Lévinas, it was concluded that for research with children, it is necessary to open oneself up to their world, and treat it as entirely diverse and autonomous. Understanding this necessity is to perceive the indispensability of otherness as an ethical presupposition of human relationships, in this case, between the researcher and the child. Only in this way will the autonomy, respect and active participation of the child be assured as a right not only in the role of a research participant but also a human being with individual characteristics that must be effectively considered.
\end{abstract}

Keywords: Human experimentation. Ethics, research. Child.

\section{Resumo}

\section{Pesquisa com crianças: leitura de Emmanuel Lévinas e a alteridade}

É recente a preocupação em delimitar a pesquisa com crianças e, mais importante, o quanto é indispensável pensá-la sob uma perspectiva ética. Com vistas à ampliação dessa discussão, objetivou-se oferecer uma forma de abordagem ética que se acredita ser essencial para o desenvolvimento de pesquisas com crianças a partir do pensamento do filósofo Emmanuel Lévinas. Com base na alteridade de Lévinas, concluiu-se que para realização de pesquisa com crianças torna-se necessário se abrir para o mundo infantil, totalmente diverso e autônomo. Perceber essa necessidade é perceber a imprescindibilidade da alteridade como pressuposto ético das relações humanas, no caso, entre o pesquisador e a criança. Somente assim, a autonomia, o respeito e a participação ativa da criança estarão assegurados como um direito que possui não apenas por ser participante de pesquisa, mas também como ser humano, com as particularidades que devem ser consideradas efetivamente.

Palavras-chave: Pesquisa envolvendo seres humanos. Ética em pesquisa. Criança.

\section{Resumen}

\section{La investigación científica con niños: una lectura de Emmanuel Lévinas en el presupuesto de la alteridad}

Es reciente la preocupación por delimitar la investigación con niños y, lo que es más importante, lo indispensable que resulta pensarla desde una perspectiva ética. Tendiendo a una ampliación de esta discusión, se tuvo como objetivo ofrecer una forma de abordaje ético que se considera es esencial para el desarrollo de investigaciones con niños a partir del pensamiento del filósofo Emmanuel Lévinas. En base a la alteridad de Lévinas, se concluyó que para la realización de la investigación con niños se hace necesario abrirse al mundo infantil, totalmente diverso y autónomo. Percibir esa necesidad es percibir la imprescindibilidad de la alteridad como un presupuesto ético de las relaciones humanas, en este caso, entre el investigador y el niño. Sólo así, la autonomía, el respeto y la participación activa del niño estarán asegurados como un derecho que posee no sólo por ser un participante de la investigación, sino también por ser un ser humano con las particularidades que deben ser consideradas efectivamente.

Palabras clave: Experimentación humana. Ética en investigación. Niño.

1. Doutoranda francine.enf07@gmail.com - Universidade Federal de Mato Grosso do Sul (UFMS) 2. Mestrando akularith@gmail.com Universidade Federal de São Carlos, São Carlos/SP 3. Doutor paulobastos@ufms.br - UFMS 4. Doutora mangelicam@ufms.br - UFMS 5. Doutora ivoms@terra.com.br - UFMS 6. Doutora alexandracarvalho@ufms.br - UFMS 7. Doutoranda isabellebr2511@gmail.com Universidade Federal do Rio Grande do Norte, Natal/RN 8. Doutor marcos_nurse@hotmail.com - UFMS, Campo Grande/MS, Brasil.

Correspondência

Francine Ramos de Miranda - Universidade Federal de Mato Grosso do Sul. Rua Lago Paranoá, 87, Vila Adelina CEP 79070-340. Campo Grande/MS, Brasil.

Declaram não haver conflito de interesse. 


\section{Research with children: a brief history}

Research involving children and adolescents has taken several approaches throughout history. In the first phase, notably in the nineteenth century, the use of children in research was unrestricted and their dignity as human beings was not recognized. One initial example was the Swedish physician Carl Janson, who stated that his research on smallpox in 1891 was carried out with 14 orphaned children. And in 1896 Albert Neisser publicly announced that he had immunized three girls and five prostitutes with plasma from patients with syphilis. Such statements caused significant repercussions and generated indignation among the populations of several countries ${ }^{1}$.

Because of such abuses, laws regulating research involving children were developed throughout the $20^{\text {th }}$ century, prohibiting their participation in such activities ${ }^{1}$. In 1901, shortly after the publication of the book "Memories of a Physician" by the Russian scientist Vikentii V. Veresaev, Prussia approved the first legislation governing research activities with human beings. Such a law explicitly prohibited research with children, after Veresaev's book described abusive research practices involving them and other vulnerable groups, described by the author as "martyrs of science" ${ }^{1}$.

Forty-six years after the Prussian legislation of 1947, the first article of the Nuremberg Code established the voluntary consent of research participants as an indispensable and essential condition when carrying out scientific investigations that conduct research on human beings. This meant that those undergoing the experiment should be legally able to consent to it. Children and adolescents were therefore excluded from research participation because of their legal incapacity ${ }^{1}$.

Changes related to research with vulnerable groups, which include children, the elderly and ethnic minorities, among other groups, are relatively recent and have accompanied changes in the broader perception of society about those groups ${ }^{1}$. In relation to children, for example, the idea of childhood and adolescence itself is relatively recent in Western societies.

At the same time, faith and optimism attributed to science during the nineteenth century were important social phenomena stimulated by the positive influence it could have on humanity, when the sacrifice of a few for the benefit of the many seemed "rational" and justifiable. The wars, genocides, and atrocities committed in the name of science in the first half of last century helped to change this perspective and strengthened the argument in favor of the importance of ethics in research, where the benefit of the majority is not a reason to violate fundamental individual rights. From this perspective emerged the basic ethical principles for research, such as the principle of autonomy, in which each participant must be fully aware of what he/she is going to do and subsequently decide to do it or not, and of justice and equity, in which everyone should benefit from research, including those directly involved in it.

The extension, recognition, and practice of these principles of research ethics for vulnerable groups has been gradual, however. It was only in 1966 that the Declaration of Helsinki made the participation of children in research possible provided the consent of their legal guardian was given. With the authorization of the participation of children in research, the evaluation of human research ethics committees has become highly judicious in the evaluation of research proposals involving this population, who are classified as vulnerable due to their inability to make discerning choices because of their obvious limitations in understanding ${ }^{2}$.

This historical summary establishes that concerns regarding the restricting of research with children are recent, and that it is essential to consider the issue from an ethical perspective. This becomes even clearer when the historical atrocities suffered by the indiscriminate use of human beings in research is considered. Based on the thought of the philosopher Emmanuel Lévinas, this study aims to describe a form of ethical approach considered essential for the development of research in this area, so broadening the discussion.

The ethics of Emmanuel Lévinas: otherness as a fundamental factor in human relationships

When dealing with reflections on research with human beings, it is essential to consider the dilemma that the scientist, as a subject desirous of knowledge, faces in relation to the appropriate behavior that must be adopted regarding the "object". Evaluating this relationship from an ethical perspective means understanding that one can only speak ethically when there is more than one person involved. In other words, intersubjective relationships, as the name suggests, only make sense when one subject comes into contact 
with another. This leads us to question how the relationship between subjects or, in the specific case of researchers and individuals taking part in research, the subject-object relationship is possible.

With an emphasis on the issue of otherness, it is important to ask: who is the Other? From an ontological perspective, the other must be understood and respected. However, there are several issues that must be considered when analyzing this theme, fundamentally regarding the vision of the Self over this Other.

Modern philosophy and science are marked by an emphasis on man as the center of philosophical restlessness. In this sense, the different areas of analysis undergo a conceptual revolution, which Kant described as a second Copernican revolution. In this manner, man ceases to orbit around a center and becomes a gravitational nucleus himself. Vázquez, meanwhile, describes such event when he states that the independence of man from the medieval God ensured his autonomy, making him the legislator and creator of his own world, based on arts, politics, science, and morals ${ }^{3}$.

The surface of this subject, freed from theological dogmas, is still markedly absolute and unchangeable. Freedom from the medieval world has not released modern reasoning from a totalizing mode of thinking, meaning that the inner and outer world is in modernity tied to objective categories, absent from temporality and spatiality. In this sense, the I becomes contradictorily captive of this definitive objectification. From the medieval age to modernity, the content has changed, but the mode of thinking has not, that means there were other dogmas, but the dual and objetificating thought remained the same. There is no longer a human-God, but the I-other relationship.

This panorama, in which the subject is seen as a master of the world, has reached today's world almost intact, and its value is evident. Emmanuel Lévinas observed that the relationship of the subject with him/herself and with the outside becomes a relationship of empowerment and absorption. In other words, Lévinas affirms that the primacy of the subject is the primacy of ontology, as the first philosophy ${ }^{4}$. The primacy of the subject is the centrality of the I in relation to the Other. Ontology, as an investigation of the Being in itself, rests upon an objectification: the permanence of the identity of the I through time. The Other makes sense only in so far as it shares the Being of the I that constitutes the relationship. The primacy of the subject or of ontology is the primacy of the Same and, thus, the negation of the Other itself. If the I is the Cartesian cogito, the modern rational individual, then only the Other whose Being is also rational may have a place in this world.

In this context, the knowledge of being is the objectification of all existing particularity. By placing the object in reflection in objective terms, horizons are delimited and common characteristics are traced, delineating what is common to the various "bodies of evidence." In short, to universalize concepts and detect the existing regularities of human beings. The difference is suppressed because of this process of totalization of thought. In his work entitled "Totality and infinity", Lévinas refers to otherness and how this concept is neglected in ontological evaluations ${ }^{5}$.

The philosopher suggests two contradictory concepts for the understanding of the human being. Here, the concept of totality consists of the annulment of the Other as a different being, and the assimilation of the Same as part of the subject. The infinite concept is defined as the acceptance of the different as different and, for this reason, impossible to be embraced in its essence by the subject. For Lévinas, the possibility of possessing, that is, of suspending the otherness of what is only the other at first sight and in relation to me, is the manner of the Same.

The opposition between totality and the infinite can be represented by the binomial I-other. For Lévinas, this duality cannot be treated only as a conceptual opposition - there is an insurmountable abyss between the I and the Other. This is the incarnation of difference, of the mysterious exterior, of the outside that is not fully revealed to the I. He affirms that to be the I is, beyond all the individualization that one can have in a system of references, to possess an identity as content ${ }^{5}$.

The I that identifies everything with his or her thinking is the same that destroys otherness, the right of the Other to be Other. The I is the suspension of the Other, or rather the transformation of what is outside into the interior. Lévinas's critique of this ontological process is based on the desire for the assimilation of the Other by the I and its complete annulment. Even if accepted to a minimal degree, otherness is only formal in order, never effective and, in the case of the interiorization carried out by the $\mathrm{I}$, the result is just the transformation of this different other into a same: the I itself.

Thus, Lévinas opposes the traditional ontology which tries at all costs to understand both the being and the Other in an objectivity capable of control and identification. In reality, the Other is the very impossibility of understanding exteriority. In being, 
however, the Other can only be accepted as a difference from the I, and not as an extension of his or her own identity.

In this way, ontology cannot be discussed when it comes to human relationships. It is important to emphasize that for Lévinas the First Philosophy cannot be ontology, but Ethics. It is a counterposition to the philosophy elaborated by René Descartes, who saw thinking as the foundation of true knowledge of the world because it is impossible to know the being of the Other, its essence. It is only possible to understand it as exteriority, veiled by the intellection of the I.

The primacy of ethics brings the need for a new relationship, a new meaning between the I and Other. A relationship that can no longer be of possession, because there is the disappearance of the subject who we seek to understand in his fullness. When the exterior ceases to exist as a different subject, it becomes an object, susceptible to manipulation, to ordination in the absence of his/ her will, and becomes the Same.

The infinite is placed here as the possibility of an authentic existence of the Other. His/her universe is inaccessible to anyone who tries to define him/her as the ontological knowledge of the Other escapes attempts at delimitation. However, even if this Other escapes understanding, he/she exists as a being that challenges the objectification of his/her existence and appearance. He/she is ahead, beside, speaks, touches another body, and his/her presence cannot be escaped. Otherness arises as a fact that must be dealt with. Moreover, how is this relationship possible? Certainly, it is not through the subjectobject binomial.

According to Lévinas, the object of knowledge, in the case of the Other, within traditional ontology, is treated in an instrumental manner, with only the subject seeking knowledge as something that is possible, which needs to be known. The neutralization of the Other, which becomes a theme or object that appears, and is placed in clarity, is precisely his or her reduction to the Same. knowing ontologically is to become an exemplar. A case that does not deserve particularities as it is its universality that is important so that the object can be generalized to fit in a theoretical concept elaborated elsewhere. Its otherness is made worthless so that its sameness can be made clear. The Other cannot be, in the proper meaning of the word, an "other", but only the Same, only what can be recognized as meaningful from the point of view of the I which elaborates the concept ${ }^{5}$.
If the Other is neutralized in this relationship for the good of generalization, then it is not possible to speak of otherness. The Other must be placed before the I, the subject in the role of subject as well. This implies the understanding that it is not possible to apprehend this Other, but only to understand that he is different and possesses, in his interiority, an indecipherable universe, the infinite that is placed before people and requires the consent of the diverse of the Same ${ }^{5}$.

If it is impossible for the I to know the Other completely, this does not mean that there is no conversation between both. This relationship cannot be performed within the sphere of totality. The relationship between the I and the Other must start from the idea of infinity. Instead of imposing his or her vision, the I needs to have an attitude of openness towards the Other, which is impossible when the Same places the different on the same level as him/her. This opening occurs through discourse. To approach others in discourse is to accept their expression where they surpass at each moment the idea that a thought could be taken from him/her. It is receiving from someone beyond the capacity of I. The breakup of the totality occurs from the moment that the I speaks to the Other, and the Other speaks to the $\mathrm{I}^{5}$.

Language in its interpretive duality is the connecting bridge or communication with the Other. In a broad sense, it functions through the common, signs objectively proposed for the understanding of the speech of the Other. In this sense, the discourse is what Lévinas considers as the said ${ }^{6}$. However, discourse contains more than conventions, offering the unequal in the role of saying, which is where in the Other cannot be placed within a totality. The exit of the I from its universe towards the Other is a learning movement, for the discourse of the I is never identical to the Other. Thus, it can be inferred that there is only discourse when there is incomprehension, in the sense of being a difference pronounced by exteriority, which in other words excludes the confrontation and the valorization of diversity, understood as an opening for the Other.

The overflowing of meaning of the Other's discourse is synonymous with equality and justice. This affinity affirms that one can only act with justice and equality when there is openness to otherness ${ }^{6}$. By standing in front of the Other as an interlocutor, one divests oneself of one's absolute power in front of him/her, allowing one to be close to the Other as a condition of thinking about his/her existence.

Difference, even if not totally understood, allows the I, placed in a hermeneutical horizon, to 
no longer seek objectification as a requirement of the I-other relationship, but the consideration of the exterior as different from me, and therefore different from my interpretive universe.

\section{Considerations on research with children from the perspective of otherness}

When considering the previous theoretical contextualization, can we think about the universe of research with children, and consider the issue of otherness regarding the instrumentalization and objectification of the relationship between researcher and child? The child as the subject is treated as an object, a fact that generates consequences and implications. In an experiential and dialogical conjecture about Lévinas, it can be said that the child treated only as an object is the destruction by the researcher of a being distinctly different from him/her and which is lost in the process of indiscriminate generalization.

Therefore, when this type of experience is imposed in any social sphere it is possible that the imprisonment of what cannot be apprehended in concepts or particular categories occurs. When looking at the child as a human being already understood by the researcher, it is observed that he/she ceases to exist as a child and begins to assume a generalized configuration through the image that is made of him/her, since it is encompassed by the totality of the subject.

The experience of these two figures becomes an one-way street in which the particularity of one (the child) is put aside for the generalization of the other (the researcher). In this space where they do not establish coexistence, but assimilation, the child as the subject is totally discarded and does not participate ethically in this relationship. The denunciation made by Lévinas about modernity and the exacerbation of the subject is relevant here. The Cartesian cogito is the idea that everything is within itself and the whole truth is intrinsic. The idea of assimilation is seen again for the "I think" from the assumption that the outside is also within the thinking subject.

The challenge of experiencing not only an ontological, but also an ethical experience, is, in a certain sense, to consent that the other cannot be summarized as "I think." The child is not within the conceptual universe of the scientist because he or she is present in the outside and nowhere else. The child is the subject and, while in this condition, has peculiarities that are unattainable and impossible to be generalized. The particularities of the child in comparison to the adolescent, adult or elderly person are related to the plurality of discursive modes of expression (verbal, non-verbal or verbal in non-conventional ways, depending on their learning stages). As much as the foundation of ethics is otherness, the specificity of children, when compared with adolescents, adults and the elderly, comes from their discursive plurality, which tends to be reduced as they grow to fit within the rational scheme of adult life.

In this sense, research with children implies an overcoming of the I-other dichotomy in the direction of a plural l-others relationship. It is a plural otherness beyond the duality of the I-other as the plurality of others is a plurality of "Is", a diversity of perspectives.

This child's voice is not that which can be lent to him or her as an abstraction. His/her body is made of flesh and not of the conceptual structures that mold it. The thinking is his/her own; it cannot be derived from a cogito that judges universally. The child's voice is different from the voice of the adult, and the child speaks in a manner that is strange to the researcher. However, the fact that he/she is a subject and his/her universe is a range of inequalities in relation to the interior and the attempt of generalization cannot be overlooked. The child confronts the objectification intended by the researcher. Conflict relationship does not allow reductionism. The bridge between both must be discourse, the scientist's offer to dialogue with the child, even if this discourse is not homonymous in every way. Language predominates the heteronomy of saying and not the absolutization of the said. Thus, the child's speech must be considered as a discourse outside Levinasian totalization, because only in this way can the subject-object relationship take a new turn and become a relationship of being-being.

The difficulty of thinking about the child as the Other goes beyond the challenge of leaving the totality of concepts towards the diverse nature of this subject. The indispensability of an ethical relationship between a scientist and a child is established before the ontological and epistemological procedure of analyzing him/her as an object only. Seeing the child as different is to open up to the possibility of considering the child as an interlocutor in the research process. Giving him/her the possibility of being authentic in his/ her difference to affirm his/her otherness without making the child's existence disappear. 
Thought of as a hermeneutic universe, the overflowing of the Being that takes it to the Other propitiates the interpretative change in relation to the child. New perspectives are formed from the moment the Other emerges from the mists of the Cartesian subject as the one that must to be considered beyond the instrumental character of the experiment.

\section{Considerations for National Ethical Guidelines}

The creation of an opening to the otherness of the child can be seen by the advances achieved in Brazilian legislation. The CNS Resolution 466/2012 of the Conselho Nacional de Saúde (the National Health Council) regulated research involving human beings since 2012, establishing that children and adolescents had the right to information about research they participate in. However, because such subjects are incapable of assessing risks, potential discomforts and benefits, and demanding their rights, consent for research participation was to be provided by the parents or guardians of the child ${ }^{7}$.

Several researchers working with children have stated, however, that although indispensable, informed parental consent could not be considered sufficient, as the practice of concentrating the decision within the adult environment is based on a paternalistic and romantic premise that the child is both an incapacitated and defenseless human being ${ }^{8}$. This is one of the greatest obstacles to performing research with children, since by infantilizing and treating them as entirely immature, the production of evidence only reinforces ideas about their incompetence ${ }^{9}$.

This is not to argue that children have the same attributes as adults, but rather a way of valuing the competence and capacity inherent in them according to their age, instead of completely discarding any possibility of autonomous expression, transferring the responsibility for decisions the child could take to adults. The fifth guideline of the Council for International Organizations of Medical Sciences (CIOMS) states that the researcher must ensure that the consent of each child is obtained to the best of his/her ability, and the child's refusal to participate in research must always be respected, unless no medically acceptable alternative exists to the treatment they are to receive, according to the research protocol ${ }^{10}$.

One of the main problems addressed is the autonomous involvement of children, requiring additional effort on the part of researchers, who need to adapt to such situations instead of dealing only with adults. The challenge of obtaining the child's assent is an attempt to extend the principles of research ethics to this group as well, rather than limiting them to adults.

Also, the child's dependence on the adult is a social rather than a natural fact, as it dependence varies according to social class. Even the definition of childhood and adolescence vary between different societies and cultures. Thus, the relationships between children and adults are heterogeneous and the values and treatments given to children are diverse. To treat child populations abstractly, without considering conditions of life is to conceal the social significance of childhood, and to neglect the real social inequality that exists among populations, including infant ones.

It is therefore necessary to recognize children as subjects rather than objects of research, which implies accepting that they can "speak up" for their own rights and report valid experiences ${ }^{8}$. In the last 20 years in Brazil an effort has been made by society to consolidate the vision of the child as a citizen, a creative subject, a social individual, and a producer of culture and history ${ }^{11}$. As an example of this movement, Law 8.069, dated July 13, 1990, created the Estatuto da Criança e do Adolescente (the Children and Adolescents Statute) (ECA), which regulates the rights of children and adolescents and was inspired by the directives provided by the Federal Constitution of 1988 , establishing several international regulations in the country ${ }^{12}$.

The ECA considers a child to be a person aged up to twelve years of age (incomplete) and treats those between twelve and eighteen years as teenagers ${ }^{11}$. Among various considerations on the rights of the child, the statute states that they have the right to opinion and expression, as well as the right to the inviolability of their autonomy ${ }^{12}$. It is based on the premise that the child is a subject of rights leading to the right to a voice and making it essential that the researcher guarantees conditions for the participation of such individuals in the decision to collaborate or not with the research ${ }^{13}$.

The duty of information requires that a research participant should know what is at stake so that he or she can make an informed decision. Such information should be provided in language that is accessible to the patient or research participant ${ }^{14}$. While investigating children, the researcher must understand that the participation of minors should be treated as an issue of different, rather than limited or inferior, complexity than researchs involving adults ${ }^{15}$. 
After 12 years of regulating research involving human beings in Brazil, MS/CNS Resolution 196/1996 was revoked by MS/CNS Resolution CNS 466, dated December 2012, which came into force following its publication in June 2013. Among its provisions, the new resolution contains information relating to the Informed Consent Form (ICF), how consent should be obtained, and issues concerning the consent of children, adolescents or the legally incapable as research participants ${ }^{7}$.

The Term of Assent (TA) does not eliminate the need to have the ICF signed by the legal guardian or legal representative of the minor ${ }^{7}$. It does, however, require the researcher to explain, in friendly and understandable language, that the child's participation in the research is voluntary and that he or she can decide whether to participate in the study or not. Obtaining the consent of children and adolescents regarding their participation in research should demonstrate, primarily, the respect of the researcher for such children.

It is therefore possible to affirm that CNS Resolution 466/2012 represents a great advance in the development of research in Brazil and reinforces the respect, dignity, and protection of research subjects. The resolution represents a step forward in respect for the autonomy of minors, allowing them to exercise their role as citizens and preserving the principle of autonomy. The Term of Assent, more than just giving the child the chance to express himself or herself, also tackles the issue of otherness and considers autonomy and respect to be fundamental ethical values in the construction of a more democratic relationship between the researcher and the child.

Although the ICF remains an indispensable legal necessity, it is important to note the progress that the Term of Assent represents for the child's view as a being that possesses self-consciousness, as well as respecting his/her existence as different and immersed in its own peculiarities. The need for the TA to be written in language that is accessible to children reflects the Levinasian view that it is only through open communication between the Self and the Other that we are able to immerse ourselves in the realm of otherness. Allowing the child to participate or not in a research study is an imperative opening to set aside the legacy of the primacy of self as the absolute evaluator of the outside world.

In this way, children must be considered as the subject and not just the object of the research. This open manner of looking at the Other is retrieved when the child becomes a participant through his/ her choice and voluntarily determines his/her own participation or otherwise in the research. This openness also allows a broader view of the universe of children by treating them not as finished pieces of information, but as structures that are always susceptible to new discoveries.

Through this new resolution, researchers wishing to involve children as participants in their research should invest intensively in the voluntary obtaining of their consent, so preserving their dignity. For this to happen, the strategies of approach regarding participation in research should consider the peculiarities of children and the needs related to their development, as well as their individual characteristics. This implies that the researcher knows how to think, feel and act at different ages so he or she can create effective strategies ${ }^{13}$.

Researchers will also need to outline a methodology that will help them avoid projecting their gaze on children, only to collect from them a reflection of their own prejudices and representations. They will therefore be required to decentralize their adult gaze so they can understand the children's world through their speech. In doing so they will have access to these children and must make themselves understood by them, treating them in their otherness and not as miniature adults.

The participation of children in research that considers their needs can be a positive experience as it gives them the opportunity to be heard by adults and to gain confidence in expressing their opinions and learning to think for themselves. Asking children to agree to participate in research through their acceptance via their signature or some other form of expression compatible with their age contributes to the valuing of such individuals, strengthening their autonomy ${ }^{16}$. It is worth emphasizing that efforts by researchers to ensure the consent of children are of great value, as coercive measures, as well as constituting unnecessary and unjustifiable physical and psychological risks, can result in unreliable data and compromise the reliability of the results presented by the research ${ }^{13}$.

Although it has developed slowly, the respect for the dignity and the valorization of children's autonomy as citizens can be perceived in the history of science and research involving the child. Such research has gradually moved from eras of total disrespect to the prohibition of their participation in research, then to protecting them from possible abuses and exploitation, and subsequently to the granting of permission for their participation in studies if authorized by their parents. 
The current status is that researchers must accept that the child must have a voice, since he or she is not inferior to adults, but simply possesses a different degree of complexity. Contrary to Cartesian thought, the child should not only be understood as data or an object but as a subject. From this emerges the new challenge of trying to understand the child and getting closer to his or her world, creating strategies that make them increasingly aware of the importance of their participation in research, as well as deciding whether or not to participate in such studies.

\section{Final considerations}

In an indiscriminate manner, from their "use" in research to the complete prohibition of their participation, the child has subsequently been readmitted, initially as a given subject understood from the perspective of the adult. Without a voice, will or active participation, the child has gradually gained space as an individual constituted of his or her own universe, different from that of the adult, who needs to express himself or herself. This is crucial to progress in such an area such as research with children, which is still new.

Taking the child as ready and finished data is a vision of him or her as a totality, and annuls his or her status as a subject composed of a structure that is different from the universe of the person who is carrying out the analysis. Research with children can therefore be based on the conception of Lévinas by opening oneself to the infinite, to the Other, to the totally diverse and autonomous world of children. To perceive this need is to perceive the indispensability of otherness as an ethical presupposition of human relationships, in this specific case, between the researcher and the child. Only then can autonomy, respect and active participation be assured as a right that the child possesses, not only as object of research but also a human being with his or her own particularities, that must be properly considered.

In addition to these observations, it is interesting to note how openness to the Other is important to avoiding the various ethical violations that have occurred in human research. Otherness, as a fundamental ethical imperative, evokes reflection on knowledge and how it can be considered as an instrument for broadening horizons, rather than merely instrumental. Understanding the need to dialogue with the Other is to understand with Lévinas that beyond the view that the Self has of the Other, there is an infinite world of perspectives that do not correspond to the imposition of the Cartesian cogito as an epistemological paradigm.

Otherness, therefore, is the very right of the Other to be Other, and not an interpretation synthesized by the Self. At this point the presence of dialogue as a heuristic instrument should be highlighted, as it links the binomial l-other. There is no need to mention the transformations evidenced in contemporary society regarding the importance of ethical thinking linked to research with human beings. The regulation of these procedures within an axiology that contemplates otherness means seeing knowledge from a perspective that considers the multiplicity of the universe of fundamental otherness. The child in this context has its existence recognized not only as a cognitive construct, but as an effective being.

The child's assent is recognized as central to conducting research involving his or her participation and an important step as it provides the opportunity for the child to have active voice and to be able to deliberate about such participation. Listening is a requirement for the insertion of dialogue in the epistemological universe of the researcher, based on the interaction of the child, taken as another, with the scientist himself, who emerges from his gravitational center to be inserted in the relation of otherness sought by Lévinas.

\section{Referências}

1. Kipper DJ, Goldim JR. Research involving children and adolescents. J Pediatr. 1999;75(4):211-2.

2. Committee on Bioethics. Informed consent, parental permission, and assent in pediatric practice. Pediatrics. 1995;2(95):314-7.

3. Vazquez AS. Ética. Rio de Janeiro: Civilização Brasileira; 1975.

4. Lévinas E. Entre nós: ensaios sobre a alteridade. Petrópolis: Vozes; 2004.

5. Lévinas E. Totalidade e infinito. Lisboa: Edições 70; 1980.

6. Ayala PC. Ética de la diferencia: ensayo sobre Emmanuel Lévinas. México: Fontamara; 2009.

7. Brasil. Conselho Nacional de Saúde. Resolução CNS no 466, de 12 de dezembro de 2012. Aprova as diretrizes e normas regulamentadoras de pesquisas envolvendo seres humanos [Internet]. Diário Oficial da União. Brasília, no 12, p. 59, 13 jun 2013 [acesso 11 maio 2017]. Seção 1. Disponível: http://bit.ly/20ZpTyq

8. Leone C. A criança, o adolescente e a autonomia. Bioética. 1998;6(1):51-4. 
9. Alderson P. As crianças como pesquisadoras: os efeitos dos direitos de participação sobre a metodologia de pesquisa. Educ Soc. 2005;26(91):419-42.

10. Council for International Organizations of Medical Sciences, Organização Mundial da Saúde. Diretrizes éticas internacionais para a pesquisa envolvendo seres humanos [Internet]. Genebra: OMS; 1993. [acesso 2 dez 2015]. Disponível: http://bit.ly/2gxbhdl

11. Kramer S. Autoria e autorização: questões éticas na pesquisa com crianças. Cadernos de Pesquisa. 2002;116:41-59.

12. Brasil. Casa Civil, Subchefia para Assuntos Jurídicos. Lei no 8.069, de 13 de julho de 1990. Dispõe sobre o Estatuto da Criança e do Adolescente e dá outras providências [Internet]. Diário Oficial da República Federativa do Brasil. Brasília; 13 de Jul 1990 [acesso 2 dez 2015]. Disponível: http://bit.ly/1MzICIG

13. Sigaud CHS, Rezende MA, Verissimo MDLR, Ribeiro MO, Montes DC, Piccolo J et al. Ethical issues and strategies for the voluntary participation of children in research. Rev Esc Enferm USP. 2009;43(2):1342-6.

14. Durand G. Introdução geral à bioética: história, conceitos e instrumentos. São Paulo: Centro Universitário São Camilo; 1999.

15. Veríssimo MLOR, Sigaud CHS, Rezende MA, Ribeiro MO. O cuidado e a ética na relação com a criança em instituições de saúde. In: Barchifontaine CP, Zoboli ELCP, organizadores. Bioética, vulnerabilidade e saúde. São Paulo: Ideias e Letras; 2007. p. 339-46.

16. Ribeiro MO, Sigaud CHS, Rezende MA, Veríssimo MLOR. Desenvolvimento infantil: a criança nas diferentes etapas de sua vida. In: Fujimori E, Ohara CVS, organizadores. Enfermagem e a saúde da criança na atenção básica. Barueri: Manole; 2009. p. 61-90.

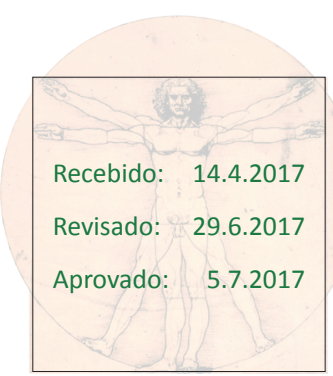

\section{Participação dos autores}

Todos os autores participaram ativamente na discussão do tópico e na elaboração e revisão do manuscrito. 